\title{
Mycobacterium w
}

National Cancer Institute

\section{Source}

National Cancer Institute. Mycobacterium w. NCI Thesaurus. Code C70969.

An attenuated strain of Mycobacterium w, a non-pathogenic, rapidly growing, atypical mycobacterium, with non-specific immunopotentiating properties. In addition to sharing a number of common B and T cell determinants with Mycobacterium leprae and Mycobacterium tuberculosis, Mycobacterium w (Mw) also shares an immunogenic determinant with prostate specific antigen (PSA). In vitro and in vivo studies have shown that heat-killed Mw can induce significant T-cell responses. This agent may induce host T-cell responses against tumor cells expressing PSA. PSA is a glycoprotein secreted by prostatic epithelial and ductal cells and may be overexpressed in prostate cancer cells. 